\title{
Role of Epidemiological Data Within the Drug Development Lifecycle: A Chronic Migraine Case Study
}

\author{
Aubrey Manack, Catherine C. Turkel and Haley Kaplowitz \\ Allergan, Inc. \\ USA
}

\section{Introduction}

By definition, pharmacoepidemiology is the study of the use and the effects of drugs, medical devices or vaccines in large numbers of people (Strom, 1994). Epidemiologists working in the pharmaceutical and biotechnology industry use the principles of descriptive epidemiology in addition to analytical and clinical epidemiological applied concepts and methods to assess the impact, use and effects of these products in the population and in clinical trial settings. As an evolving field, the influence of pharmacoepidemiology continues to be broadened with increasing demands for a comprehensive understanding of the patient population within the development and post-authorization phases of a product's lifecycle.

Before exploring the role of epidemiology within the drug lifecycle, some familiarity with the phases of drug development is necessary. Herein, a brief overview of the drug development lifecycle is provided. The intent is not to present a detailed outline of the regulatory process by which a new drug is brought to market, but rather a selective review to offer context for the potential clinical and scientific contributions of the field of epidemiology. The established framework of a drug's lifecycle includes four phases: discovery and research (pre-clinical phase), clinical development, regulatory review and approval, and post-authorization (Table 1). Typically, discovery begins with industry or academic researchers testing tens of thousands of compounds to determine potential therapeutic benefit. Few compounds proceed to the next stage, which involves testing candidate drugs in animals to ensure there is no development of limiting toxic effects. It is estimated that only 1 out of 50 candidate drugs will move past the discovery phase and into clinical development trials in humans (phases I, II and III). Clinical trials in humans represent the most expensive phase of development. Cost estimates range in the hundreds of millions, and for every five drugs entering late-phase clinical trials, only one will eventually make it to market and generate revenue for the manufacturer (Tufts, 2001). Additionally, during this time, there is ongoing parallel work related to drug substance manufacturing (e.g., formulation activities, analytical and microbiological methods development and validation) to support development activities. 


\begin{tabular}{|c|c|c|c|}
\hline Phase & Title & Timing & Brief Description \\
\hline Preclinical & $\begin{array}{l}\text { Discovery and } \\
\text { research }\end{array}$ & $\begin{array}{l}1 \text { to } 6 \\
\text { years }\end{array}$ & $\begin{array}{l}\text { Preclinical testing - initiation for synthesis, } \\
\text { purification and formulation of the drug; for } \\
\text { conducting biology/pharmacology, } \\
\text { pharmacokinetics and metabolism evaluations; } \\
\text { for conducting GLP toxicity/safety evaluations } \\
\text { including toxicology, pathology, mechanistic } \\
\text { toxicology and bioanalytical support; for } \\
\text { identification of potential drug-drug interactions. }\end{array}$ \\
\hline Phases I-III & $\begin{array}{l}\text { Clinical } \\
\text { development }\end{array}$ & $\begin{array}{l}6 \text { to } 11 \\
\text { years }\end{array}$ & $\begin{array}{l}\text { Phase I - The "safety" phase. Smaller clinical } \\
\text { trials using healthy volunteers to determine the } \\
\text { drug's basic pharmacokinetic and } \\
\text { pharmacologic properties and safety profile in } \\
\text { humans. } \\
\text { Phase II - The "learn" phase. These trials are } \\
\text { focused on evaluating effective and safe doses } \\
\text { in persons with the target disease/disorder } \\
\text { under consideration. } \\
\text { Phase III - The "confirm" phase. These trials are } \\
\text { usually the most extensive and most expensive } \\
\text { part of drug development. These trials often are } \\
\text { controlled (usually with placebo) and are } \\
\text { designed to verify the safety and efficacy of a } \\
\text { drug in large numbers, typically several } \\
\text { hundred to several thousand persons, within } \\
\text { the target population. }\end{array}$ \\
\hline $\begin{array}{l}\text { Peri- } \\
\text { approval }\end{array}$ & $\begin{array}{l}\text { Regulatory } \\
\text { review and } \\
\text { approval }\end{array}$ & $\begin{array}{l}0.6 \text { to } 2 \\
\text { years }\end{array}$ & $\begin{array}{l}\text { After completing phases I-III, the manufacturer } \\
\text { submits a registration dossier containing all non- } \\
\text { clinical (eg, toxicology, pharmacology), efficacy } \\
\text { and safety data in addition to manufacturing } \\
\text { quality data for review by regulatory agencies } \\
\text { (eg, FDA - United States Food and Drug } \\
\text { Administration, EMA - European Medicines } \\
\text { Agency). The agency evaluates the drug's safety, } \\
\text { efficacy and labeling with specific emphasis on } \\
\text { public health impact and the benefit-risk profile } \\
\text { of the drug. }\end{array}$ \\
\hline Phase IV & $\begin{array}{l}\text { Post- } \\
\text { authorization/ } \\
\text { Post-market } \\
\text { surveillance }\end{array}$ & $\begin{array}{l}11 \text { to } 14 \\
\text { years }\end{array}$ & $\begin{array}{l}\text { Conditioned on the regulatory approval of the } \\
\text { drug and involves ongoing safety evaluation of } \\
\text { the drug (through periodic spontaneous } \\
\text { reports, which may also be supplemented with } \\
\text { observational studies) once it is used within the } \\
\text { real-world setting with the emphasis of } \\
\text { maintaining the benefit-risk profile. }\end{array}$ \\
\hline
\end{tabular}

Adapted from FDA review.org. http://www.fdareview.org/approval_process.shtml and Hartzema et al., 1998 .

Table 1. Description of drug development lifecycle. 
Epidemiological data and methods are utilized during each phase presented above; however, the degree of involvement is dependent on the current knowledge base and interactions between factors that are specific to the molecule (eg, biologic vs. drug; oral vs. injectable), the disease (eg, hypertension vs. cancer), other inventions (eg, competitive and/or complimentary products) and the patient (eg, males in their mid-40s vs. adolescent females) (Figure 1). Furthermore, underlying these interactions is the impact of patient's knowledge, attitude and behaviors about the study drug or disease as well as interactions with the geographical and social environment.

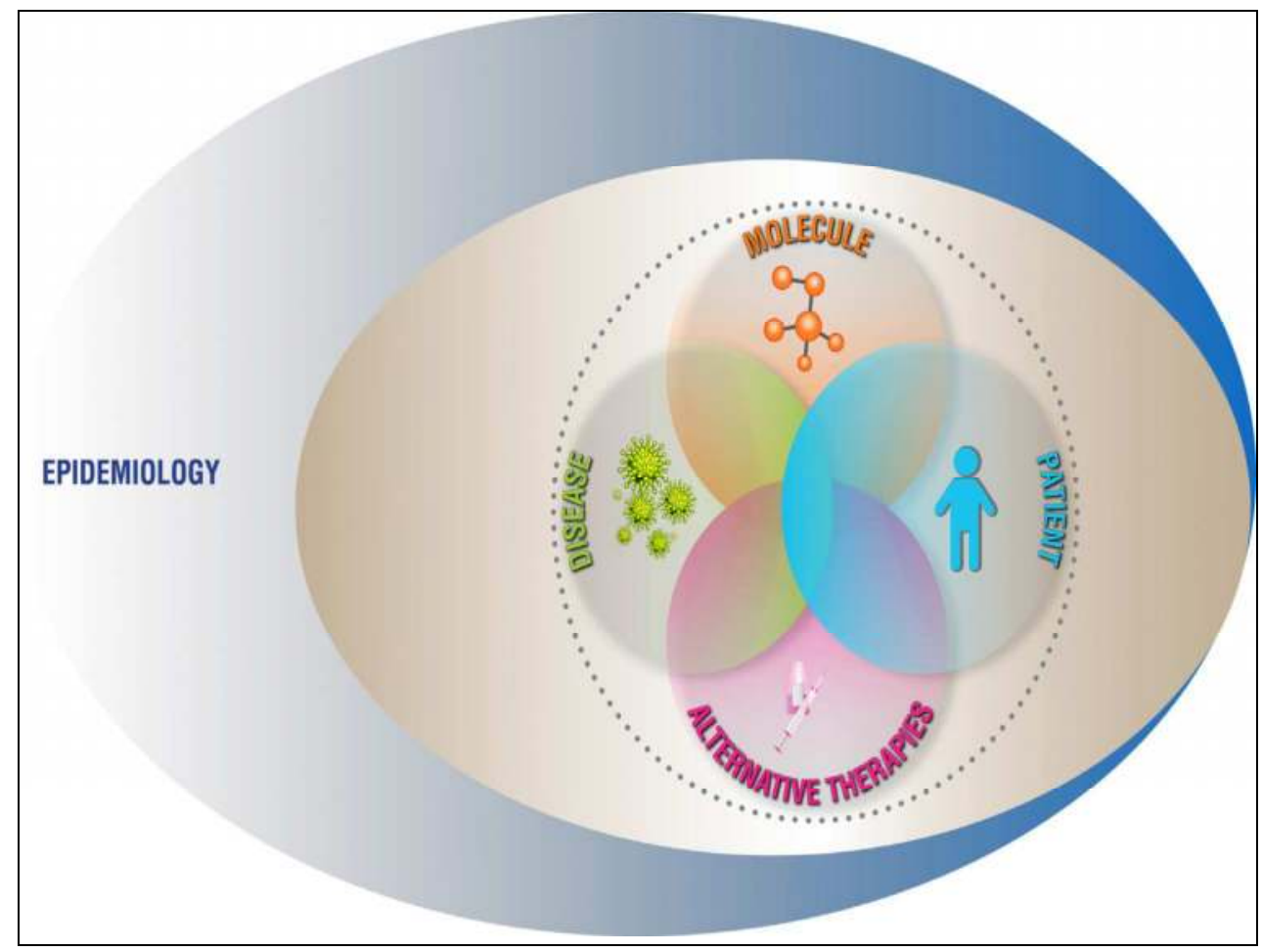

Fig. 1. Conceptual framework for the potential impacts for epidemiological data and methods within the clinical development phase

As there is a wide spectrum of data needs and requirements during any drug's lifecycle, a summary, including a real-world example, of the epidemiological data and methods utilized specifically during clinical development phase is helpful. To illustrate how epidemiologists can facilitate clinical development, this review provides a practical overview of the type of research questions addressed with epidemiological data and methods. In addition, a case study describing how epidemiological data was used to support the registration of onabotulinumtoxinA (BOTOX ${ }^{\circledR}$, Allergan, Inc., Irvine, CA, USA) for treatment of headaches in adults with chronic migraine is presented. Using this framework, data generation is focused on the population epidemiology, treated natural history and burden of chronic migraine. The review is not meant to be a guidance document, but rather an illustration 
highlighting the importance of an evidence-based understanding of the patient population in order to adequately measure efficacy, to evaluate and maintain the safety of a drug during development and to prepare for post-registration activities once the product is available in the market. Although not the focus of this chapter, the role of pharmacoepidemiologists does not end at approval. In the post-authorization environment, the need shifts more toward understanding the patient population actually exposed to the drug, under what conditions, and with what outcomes, in the "real world" setting. For example, is the drug being used in patients not included in clinical trials? Is there compliance with the labeling? Is the safety and effectiveness similar to what was observed in clinical trials? If not, why not? To respond to these types of research questions, designs such as drug utilization studies, post-authorization safety and effectiveness studies should be explored.

\section{Defining the target patient population}

Epidemiology data can be used to estimate the size of the target population and its geographic distribution, quantify and describe demographic and clinical characteristics, and help determine the potential public health impact of a target treatment once the drug is marketed and prescribed within the general population. These data are critically important to help guide commercial and clinical development strategies; therefore, it is most useful to obtain this information starting early in phase II and continuing, as needed, through phase III.

By the time a drug enters clinical development, a sponsor (e.g. pharmaceutical or biotechnology company) has typically already assessed, at least at a high level, the incidence and prevalence of disease, the unmet needs for treatment, and the burden of disease, in order to have some understanding of where the drug might fit in the treatment armamentarium.

During the phase II and phase III clinical trials, a more robust understanding of the target patient population becomes necessary in order to evaluate efficacy and safety and to consider the optimal position within the current treatment paradigm. Therefore, epidemiologists rely on observational study design (eg, disease registries, cohort studies, cross-sectional studies, case-control studies) to generate data to answer more specific questions about the population epidemiology and disease natural history. (Strom, 1994; Hartzema et al., 1998) The population epidemiology of a disease provides estimates of the total number of people currently impacted as well as future estimates by utilizing current and projected prevalence and incidence rates. Aiming to stratify prevalence and incidence rates by country or geographic region, age, gender and, when appropriate, factors such as race or seasonal variation can provide a more complete picture of the demographic profile of the target population. Additionally, the symptom profile, disease-related morbidity and mortality, should be detailed in this context. The disease natural history refers to the progression of a disease from onset until either recovery or death. It encompasses factors related to the behavior of a disease so that the clinical course including the disease onset, disease duration, progression, and disease outcomes are well documented. Available treatment practices should be evaluated, as this often alters disease progression. Risk factors, including biological, genetic or environmental, should be discussed in terms of disease outcomes or progression rather than onset. It is worth noting that because typical drug development, with the exception of vaccine development, is not focused on disease prevention, but rather remission or recovery, then the focus is on understanding factors that alter disease duration and endpoints rather than disease onset and is referred to as the treated natural history. 
Observational studies are used to generate data describing the target patient population in the "real world" rather than in the controlled "clinical trials" environment. Multiple observational approaches can be utilized, depending on research objectives. Cross-sectional studies collect data on various characteristics, experiences and behaviors in relation to exposure, outcomes and/or other variables of interest at the same time point. These studies can be either population-based or represent a select population, such as those in a clinic or those who have access to the internet. Cohort studies can be conducted prospectively or retrospectively, and identify and follow subjects according to either exposure or disease occurrence to assess multiple outcomes. Commonly utilized examples cohort studies include retrospective electronic health care database analyses and disease registries. Casecontrol studies are typically hypothesis testing, in that the design aims to quantify the odds of having an exposure given an outcome or the reverse depending on what is known. Subjects are predefined as either case or controls based on whether the patient has the disease or outcome of interest, and then patients' histories are compared for differences in exposure or other potential risk factors. When evaluating which study design is most appropriate, pharmacoepidemiologists assess and select study designs based on the particular research question, urgency of the data request, availability of data sources, concerns of internal and external validity, and feasibility and practicality, and cost (Hartzema et al., 1998).

It is not feasible to discuss every situation for which epidemiological data can be utilized in a single chapter; however, one of the key drivers of research is the need to put into context the clinical trial findings, for example, when monitoring safety within double-blind, placebocontrolled trials. In order for safety physicians to effectively monitor safety without unblinding patients in clinical trials, outcomes that are associated with natural disease course should be distinguished from adverse outcomes that are potentially drug-related, referred to as adverse drug reactions. This situation encompasses the potential for confounding by indication and reflects the importance in adequately "teasing apart" adverse events caused by the disease itself versus adverse events caused by the drug, or even a potential disease-drug interaction or when the adverse event may occur in the disease background but be exacerbated or prolonged by the drug. To clarify with examples, confounding is when a variable (e.g., adverse event such as weight gain) is a risk factor for a disorder (e.g., CM) among nonexposed persons (e.g., those not on study drug) and is associated with the exposure of interest (e.g., study drug) in the population from which the cases derive, without being an intermediate step in the causal pathway between the exposure and the disorder (Salas M et al., 1999). Given the potential complexity of natural clinical course of a disease, it is evident that if background rates within the target population unexposed to the drug are adequately quantified, then the determination of drug- or disease-related outcomes can be strengthened beyond the clinical assessment of treatment causality.

By answering questions in Table 2, row 1, epidemiologists support clinical development by providing strategic insight into defining the appropriate target patient profile and the predicted public health benefit. Defining diagnostic criteria and properly characterizing the target patient population will help in understanding the disease outside the clinical trial environment to ensure that clinical trials are evaluating treatments in the most appropriate target patient population. Epidemiological data can also help physicians monitor the safety without unblinding patients in clinical trials, and if a potential risk is identified, can help to estimate the impact in actual clinical practice. 


\begin{tabular}{|c|c|c|}
\hline Category & Description & Key Research Questions \\
\hline $\begin{array}{l}\text { Population } \\
\text { Epidemiology }\end{array}$ & $\begin{array}{l}\text { An overview of the condition } \\
\text { for which the product is being } \\
\text { developed, including } \\
\text { incidence rate (rate of new } \\
\text { cases in a population within a } \\
\text { specified time frame), } \\
\text { prevalence rate (number of } \\
\text { existing cases) stratified by } \\
\text { geography, patient } \\
\text { demographics in a population } \\
\text { within a specified time frame, } \\
\text { clinical characteristics, trends } \\
\text { over time and } \\
\text { recommendations relating to } \\
\text { studies needed to address data } \\
\text { gaps }\end{array}$ & $\begin{array}{l}\text { - What are the disease rates (eg, age-, } \\
\text { gender-stratified)? More specifically, } \\
\text { which populations are most affected } \\
\text { both currently and prospectively by } \\
\text { the disease? } \\
\text { - What is the disease severity in relation } \\
\text { to morbidity and mortality? } \\
\text { - What is the disease duration? } \\
\text { - What is the severity of the disease } \\
\text { symptoms in relation to disease } \\
\text { duration? } \\
\text { - What are the characteristics (eg, age, } \\
\text { correlated clinical deficiencies) of the } \\
\text { disease onset? } \\
\text { - What are the key drivers (eg, comorbidity } \\
\text { profile, health care access) with regard } \\
\text { to disease progression? }\end{array}$ \\
\hline $\begin{array}{l}\text { Treated } \\
\text { Natural } \\
\text { History }\end{array}$ & $\begin{array}{l}\text { An overview of clinical course } \\
\text { of the condition for which the } \\
\text { product is being developed. } \\
\text { Focused on detailing disease } \\
\text { progression, defining a patient } \\
\text { profile, quantifying rates of } \\
\text { common comorbidities, } \\
\text { treatments and treatment } \\
\text { practices, disease outcome } \\
\text { rates (e.g. morbidity, } \\
\text { mortality, survival) and rates } \\
\text { of potential drug-related } \\
\text { adverse events. This report } \\
\text { provides information to } \\
\text { understand the types of } \\
\text { adverse events that are } \\
\text { associated with the planned } \\
\text { indication and with its } \\
\text { common therapies and to } \\
\text { quantify the frequency (ie, } \\
\text { risk) of these adverse events } \\
\text { within the general population } \\
\text { and to estimate the potential } \\
\text { benefit of the product under } \\
\text { development. }\end{array}$ & $\begin{array}{l}\text { - What are the characteristics of the } \\
\text { disease onset? } \\
\text { - Age } \\
\text { - Correlated deficiencies } \\
\text { - Potential covariates (eg, stress, } \\
\text { environmental triggers) } \\
\text { - What are the characteristics of the } \\
\text { disease window? } \\
\text { - How long does the average person } \\
\text { have the disease? } \\
\text { - What occurs in extreme cases? } \\
\text { - What are the common } \\
\text { comorbidities? } \\
\text { - Understand differences with regard } \\
\text { to factors such as: } \\
\text { - Nutrition } \\
\text { - Psychology } \\
\text { - Health care } \\
\text { - Socioeconomic status (SES) } \\
\text { - What are the characteristics of the } \\
\text { disease endpoint? } \\
\text { - Does disease endpoint depend on } \\
\text { disease severity? } \\
\text { - Outline major and minor effects of } \\
\text { the disease: } \\
\text { - Are there any permanent losses } \\
\text { of ability? } \\
\text { - Correlate that loss of ability to } \\
\text { quality of life }\end{array}$ \\
\hline
\end{tabular}




\begin{tabular}{|c|c|c|}
\hline Category & Description & Key Research Questions \\
\hline & & $\begin{array}{c}\text { - Understand the percentage of } \\
\text { reoccurrence of disease after } \\
\text { initial onset } \\
\text { - What is the disease profile, combining } \\
\text { genetic, environmental and cultural } \\
\text { factors that may contribute to disease? } \\
\text { - Who is most likely to be diagnosed } \\
\text { with the disease? } \\
\text { - Who is most likely to have severe } \\
\text { progression of the disease? } \\
\text { - Are there cultural biases in relation } \\
\text { to treatment and/or disease? }\end{array}$ \\
\hline $\begin{array}{l}\text { Burden of } \\
\text { Disease }\end{array}$ & $\begin{array}{l}\text { An overview focused on the } \\
\text { negative disease-related } \\
\text { impact for the individual } \\
\text { suffering and his or her social } \\
\text { network, as well as the } \\
\text { associated direct and indirect } \\
\text { costs in the real-world setting. }\end{array}$ & $\begin{array}{l}\text { - What is the humanistic burden } \\
\text { associated with the disease? } \\
\text { - Health-related quality of life } \\
\text { assessments } \\
\text { - Disability assessments } \\
\text { - Disease-related impacts (eg, } \\
\text { depression, anxiety, sleep) } \\
\text { - What is the societal burden associated } \\
\text { with the disease? } \\
\text { - Associated family and social burden } \\
\text { - Lost employment/education (ie, } \\
\text { absenteeism) } \\
\text { - Suboptimal work productivity (ie, } \\
\text { presenteeism) } \\
\text { - Caregiver burden } \\
\text { - What is the economic burden associated } \\
\text { with the disease? } \\
\text { - What are the direct costs associated } \\
\text { with the disease? } \\
\text { - Healthcare encounters (eg, } \\
\text { emergency room (ER) visits, } \\
\text { hospitalizations, office visits) } \\
\text { - Over-the-counter and } \\
\text { prescription medications } \\
\text { - Treatment-related procedures } \\
\text { - Diagnostic evaluations } \\
\text { - Patient co-payments } \\
\text { with the disease? } \\
\text { schootized assessment of work- or } \\
\text { - Absenteeism and presenteeism }\end{array}$ \\
\hline
\end{tabular}

Table 2. Overview of epidemiology support for clinical development. 
Real-world application can provide significant insights when discussing the role of epidemiology within the pharmaceutical or biotechnology development industry. When the onabotulinumtoxinA development program for chronic migraine was initiated, the International Headache Society had not standardized diagnostic criteria for chronic migraine, which had broadly been defined as those with migraine and 15 or more headache days per month. In subsequent years, and in parallel to the phase II and phase III trials, multiple diagnostic criteria were proposed to the clinical community and it proved difficult to create criteria applicable to clinical practice, clinical trials and population-based studies. As a consequence, a wide range of terms with a multiplicity of definitions were applied to persons with what is now defined as chronic migraine (Manack et al., 2009, 2010; Olesen 2006; Olesen et al., 2006). Due to the timing of this evolution relative to when the onabotulinumtoxinA trials were completed, the chronic migraine diagnostic criteria utilized in the phase III studies were in alignment, but were not identical to the most recent criteria proposed by the International Headache Classification Committee within the International Classification of Headache Disorders (ICHD) guidelines.

To ensure that the safety and efficacy trial findings were representative of findings for those diagnosed under the most recent ICHD criteria (ICHD-2R), profile concordance between criteria was evaluated within a large patient population that physicians identified as having chronic migraine. Epidemiological assessments of daily diary data were completed to compare the demographic and headache symptom profiles for the several of the proposed chronic migraine diagnostic criteria (Silberstein et al., 2011; Lipton et al., 2011). Within the test database, the ICHD-2R definition was set as the gold standard and sensitivity and specificity analyses against the onabotulinumtoxinA phase III diagnostic criteria were conducted. Assessments supported that the patient profiles of the chronic migraine diagnostic groups were similar across demographic profiles and headache characteristics. Results from the epidemiological assessments all supported the initial hypothesis that the chronic migraine population evaluated in the phase III clinical studies was not identical to, but was clinically representative of, the target population of patients currently defined by the ICHD-2R criteria and fully representative of patients who would be receiving onabotulinumtoxinA treatment.

Additionally, due to the chronic migraine classification variability, it was difficult to determine the disease prevalence during the time of the development program. To gain a better understanding of the actual number of people suffering from chronic migraine, a systematic literature search was conducted to summarize population-based studies reporting prevalence and incidence of chronic migraine and to explore variation across studies. Sixteen publications representing 12 studies were accepted as having a relevant study design and population. None presented data on chronic migraine incidence. The prevalence of chronic migraine ranged between 0 and $5.1 \%$, with estimates typically in the range of 1.4-2.2\% (Natoli et al., 2010). Prevalence varied by World Health Organization region and gender. Heterogeneity across studies and lack of data from certain regions left an incomplete picture; however, the review offered a comprehensive overview of the current knowledge base and provided direction for future research (Natoli et al., 2010).

Expanding beyond the assessments of drug safety and efficacy, the onabotulinumtoxinA development program incorporated a significant amount of epidemiological research to 
generate data that established the clinical course of chronic migraine and distinguished it from episodic migraine (migraine with less than 15 days of headache per month). Three robust epidemiological studies were utilized as data sources (Table 3). Of note, and emphasizing the collaboration between academia and industry, only one of these studies was initiated and completely sponsored by the manufacturer.

\begin{tabular}{|c|c|c|c|}
\hline Study & Design & Duration & Sponsorship \\
\hline $\begin{array}{l}\text { American } \\
\text { Migraine } \\
\text { Prevalence and } \\
\text { Prevention } \\
\text { (AMPP) Study } \\
\text { (Buse et al., 2010; } \\
\text { Lipton et al., } \\
\text { 2007) }\end{array}$ & $\begin{array}{l}\text { Longitudinal, prospective, } \\
\text { population-based, mailed } \\
\text { survey identified } \\
\text { individuals by screening } \\
120,000 \text { US households } \\
\text { representative of the US } \\
\text { population, resulting in a } \\
\text { pool of } 24,000 \text { respondents } \\
\text { with severe headache who } \\
\text { have been followed } \\
\text { annually. }\end{array}$ & 5 years & $\begin{array}{l}\text { Study initially funded by } \\
\text { an unrestricted grant to the } \\
\text { National Headache } \\
\text { Foundation by Ortho- } \\
\text { McNeil Neurologics, Inc., } \\
\text { Titusville, NJ, USA. } \\
\text { Additional analyses and } \\
\text { data collection focused on } \\
\text { chronic migraine } \\
\text { epidemiology funded by } \\
\text { Allergan Inc., Irvine, CA. }\end{array}$ \\
\hline $\begin{array}{l}\text { German } \\
\text { Headache } \\
\text { Consortium } \\
\text { (GHC) Study } \\
\text { (Katsarava et al., } \\
\text { 2011) }\end{array}$ & $\begin{array}{l}\text { Longitudinal, prospective, } \\
\text { population-based, } \\
\text { mailed/telephone survey } \\
\text { used questionnaires sent } \\
\text { annually to a random } \\
\text { sample of } 18,000 \\
\text { individuals aged 18-65 } \\
\text { residing in } \\
\text { demographically diverse } \\
\text { regions, including a large } \\
\text { and midsize city and a } \\
\text { rural area of Germany. }\end{array}$ & 3 years & $\begin{array}{l}\text { Study funded by the } \\
\text { German Research Council } \\
\text { (DFG), German Ministry of } \\
\text { Education and Research } \\
\text { (BMBF), and European } \\
\text { Union and conducted } \\
\text { through the Department of } \\
\text { Neurology in Essen. } \\
\text { Additional analyses } \\
\text { focusing on chronic } \\
\text { migraine epidemiology } \\
\text { supported by Allergan, } \\
\text { Inc., Irvine, CA, USA. }\end{array}$ \\
\hline $\begin{array}{l}\text { International } \\
\text { Burden of } \\
\text { Migraine Study } \\
\text { (IBMS) } \\
\text { (Blumenfeld et } \\
\text { al., 2011; Payne } \\
\text { et al., 2011) }\end{array}$ & $\begin{array}{l}\text { Cross-sectional web-based } \\
\text { survey identified panelists } \\
\text { through respondents who } \\
\text { had previously reported } \\
\text { suffering from headaches } \\
\text { or migraine. Nine } \\
\text { countries surveyed: United } \\
\text { States, Canada, Germany, } \\
\text { United Kingdom, France, } \\
\text { Italy, Spain, Australia and } \\
\text { Taiwan. }\end{array}$ & 1 year & $\begin{array}{l}\text { Study funded by Allergan, } \\
\text { Inc., Irvine, CA, USA. }\end{array}$ \\
\hline
\end{tabular}

Table 3. Summary of chronic migraine epidemiological studies 
Data from the three independent studies (AMPP study, GHC study, IBMS) concluded that the two headache disorders (chronic migraine and episodic migraine) differ with regard to clinical definitions, prevalence, symptom profiles, functional consequences and disabilities, indirect and direct costs, patterns of consultation and treatment, rates of comorbidities and risk factors (Manack et al., 2010, 2011; Bigal et al., 2008, Buse et al., 2010, 2011 in press; Blumenfeld et al., 2011; Katsarava et al., 2011; Stewart et al., 2010; Munakata et al., 2009). Data confirmed what had been previously hypothesized by the headache community: that chronic and episodic forms of migraine exist along a clinical spectrum with remission and progression between the two, but the disorders are distinct and differ in degree and kind (Lipton, 2009; Lipton and Chu, 2009) (Table 4).

\begin{tabular}{|c|c|c|}
\hline Variable & Chronic Migraine & Episodic Migraine \\
\hline Clinical description & $\begin{array}{l}\text { ICHD- } 2 \text { criteria for migraine } \\
\text { and average } \geq 15 \text { headache } \\
\text { days/month }\end{array}$ & $\begin{array}{l}\text { ICHD- } 2 \text { criteria for migraine } \\
\text { and average }<15 \text { headache } \\
\text { days/month }\end{array}$ \\
\hline Prevalence, $\% * *$ & $1.4-2.2$ & 11 \\
\hline Age, mean (SD) & $47.7(14.0)$ & $46.0(13.8)$ \\
\hline Race, \% Caucasian & 78.6 & 80.0 \\
\hline BMI, mean (SD) & $29.8(8.3)$ & $29.2(7.9)$ \\
\hline Cutaneous allodynia, \% & 68.2 & 63.2 \\
\hline $\begin{array}{l}\text { Headache duration } \\
\text { with medication } \\
\text { (average in hours) } \\
\text { mean SD }\end{array}$ & $24.1(46.8)$ & $12.8(25.0)$ \\
\hline $\begin{array}{l}\text { Headache duration } \\
\text { without medication } \\
\text { (average in hours) } \\
\text { mean SD }\end{array}$ & $65.1(62.2)$ & $38.8(39.9)$ \\
\hline $\begin{array}{l}\text { Headache pain } \\
\text { intensity, \% severe }\end{array}$ & 92.4 & 78.1 \\
\hline Comorbid conditions & $\begin{array}{l}\text { More likely to report or meet } \\
\text { criteria for psychiatric, pain, } \\
\text { respiratory and } \\
\text { cardiovascular comorbid } \\
\text { conditions }\end{array}$ & $\begin{array}{l}\text { Less likely to report or meet } \\
\text { criteria for psychiatric, pain, } \\
\text { respiratory and } \\
\text { cardiovascular comorbid } \\
\text { conditions }\end{array}$ \\
\hline
\end{tabular}

*Significantly different finding reported in published AMPP study and IBMS data (Bigal et al., 2008; Buse et al., 2010; Blumenfeld et al., 2011; Buse et al., 2011 in press)

**Sources: Natoli et al., 2010; Lipton et al., 2007.

Table 4. Examples of differences* between chronic migraine and episodic migraine

\section{Defining the burden}

Due to high healthcare costs, manufacturers are under increasing scrutiny by regulators, policy-makers, employers and consumers to demonstrate the clinical and economic value 
of a new drug being brought to market. Given this environment, there is an evolving view that the drug approval process is expanding beyond the determination of a drug's safety and efficacy to include data on comparative effectiveness of a new drug to one or more available therapies. Comparative effectiveness is defined by the Institution of Medicine as "the comparison of effective interventions among patients in typical patient care settings with decisions tailored to individual patient needs" (Doyle, 2011; Sox \& Greenfield, 2009). According to global regulations, demonstrating comparative effectiveness is not required for commercial license; however, it is often required for reimbursement by national and/or private insurance providers. Specifically, health technology assessments (HTAs) are the appraisal process by which public and private payers evaluate economic value (Doyle, 2011). In effect, establishing a positive economic value impact has become a milestone within the regulatory review and approval of a drug's lifecycle. By addressing research questions highlighted in Table 2, row 3, epidemiologists support industry health economists and outcomes researchers in the development of the economic value story by providing strategic insight into real-world disease-related burden and resource utilization.

In order to evaluate the real-world value of a drug, many factors and modeling techniques that are beyond the scope of epidemiology are employed (Gold et al., 1996; Briggs et al., 2006). However, epidemiological data and methods can support health economists in determining strategy and inputs into economic impact models. A key component when assessing the potential value impact of a new drug is to establish the current humanistic, societal and economic burden for the disease of interest within the real world. Phase III clinical trials are often designed to assess impacts on disease-related burden and economic consequences, which include but are not limited to data to evaluate health-related quality of life, disability, healthcare encounters and/or workplace impact. However, as burden and economic outcomes within a clinical trial setting may not represent outcomes in the real world, there is a recognized benefit to supporting the clinical trial data with populationbased assessments that quantify burden and resource utilization (Doyle, 2011; Murray \& McElwee, 2010; Conway \& Clancy, 2010).

Through leveraging epidemiological data, the humanistic, economic and societal burden associated with chronic migraine was established during the development program. Specifically, data from the AMPP study, GHC study, and IBMS (Table 3 for study designs) was utilized to quantify the burden that frequent migraine attacks pose on patients, their families and employers, and healthcare systems.

In summary, chronic migraine was determined to be a disabling, underdiagnosed and costly disorder (Bigal et al., 2008; Blumenfeld et al., 2011; Manack et al., 2011), particularly when compared to episodic migraine. Those with chronic migraine often spend at least half their days suffering from debilitating pain and associated symptoms of nausea, vomiting, photophobia and phonophobia (Bigal et al., 2008; Manack et al., 2011). Data support the substantial direct and indirect treatment-associated costs as well as significantly increased interference on normal life activities, such as the ability to work or perform routine chores and build and maintain functional family, social and community relationships, for those with chronic migraine when compared to episodic migraine (Table 5). 


\begin{tabular}{|c|c|c|}
\hline Variable & Chronic Migraine & Episodic Migraine \\
\hline $\begin{array}{l}\text { Depression, } \% \text { meeting } \\
\text { criteria for clinical depression }\end{array}$ & 25.2 & 10 \\
\hline $\begin{array}{l}\text { Headache Impact Test (HIT- } \\
6), \% \text { in "severe" category }\end{array}$ & 72.9 & 42.3 \\
\hline $\begin{array}{l}\text { Headache-related treatment } \\
\text { costs, mean US dollars }\end{array}$ & $\$ 1036$ per 3 months & $\$ 383$ per 3 months \\
\hline Employment, \% on disability & $20(1$ in 5$)$ & $10(1$ in 10$)$ \\
\hline $\begin{array}{l}\text { Headache-related Lost } \\
\text { Productive Time (LPT)* }\end{array}$ & $\begin{array}{l}50 \% \text { of sufferers lost more } \\
\text { than } 2 \text { hours per } 2 \text { weeks }\end{array}$ & $\begin{array}{l}16 \% \ddagger \text { of sufferers lost more } \\
\text { than } 2 \text { hours per } 2 \text { weeks }\end{array}$ \\
\hline \multirow[t]{2}{*}{$\begin{array}{l}\text { LPT associated cost, US } \\
\text { dollars per week }\end{array}$} & $\begin{array}{l}\text { Women aged } 25-64 \text { years: } \\
\$ 61.51-\$ 118.64 \text { per week } \\
\text { per person }\end{array}$ & $\begin{array}{l}\text { Women aged } 25-64 \text { years: } \\
\$ 30.80-\$ 46.49 \text { per week per } \\
\text { person }\end{array}$ \\
\hline & $\begin{array}{l}\text { Men aged } 25-64 \text { years: } \\
\$ 62.13-\$ 287.12 \text { per week } \\
\text { per person }\end{array}$ & $\begin{array}{l}\text { Men aged } 25-64 \text { years: } \\
\$ 53.15-\$ 86.82 \text { per week per } \\
\text { person }\end{array}$ \\
\hline
\end{tabular}

*LPT is the sum of self-reported absenteeism and presenteeism during a 2-week period.

†Significantly different findings were reported in the AMPP study and IBMS (Bigal et al., 2008; Stewart et al., 2010; Blumenfeld et al., 2011; Buse et al., 2011 in press; Stokes et al., 2011; Manack et al., 2012;

Serrano et al., 2011, in progress)

$\ddagger$ Based on those with fewer than 10 headache days per month.

Table 5. Examples of burden of chronic migraine compared to episodic migraine ${ }^{\dagger}$

\section{Post-approval pharmacoepidemiology plan}

The approval to market a drug, device or vaccine depends primarily on the results of the clinical trial program which includes investigational trials with a variety of potential designs; generally, randomized, double-blind placebo-controlled studies are considered the gold standard. However, even these studies are not without limitations, including relatively small sample sizes, selective populations, short follow-up, use of intermediate (surrogate) endpoints and limited generalizability (Glasser et al., 2007). Furthermore, problems seen after product approval has placed demands on manufacturers, regulators and policy makers to more effectively monitor and expand the knowledge of safety in the post-authorization period. This requires a proactive plan, including an assessment of research gaps and appropriate study designs, beginning in the clinical development phase so that strategies can be initiated upon drug approval.

Post-marketing research, or more specifically phase IV studies, can either be interventional or non-interventional by design, with epidemiologists typically focusing on those that are non-interventional. Again, descriptive or observational designs are used to evaluate drug utilization patterns; additionally, with a study design that allows for exposure in a broader range of patients, more real-world information about the 
drug's safety and effectiveness can be captured (Wise, 2011; Glasser et al., 2007). Analytical epidemiology or the design, execution and analysis of studies to evaluate potential associations between exposure and outcome, has a defined role within pharmacovigilance, which deals with the detection, assessment, understanding and prevention of adverse effects or other drug-related problems (Wise, 2011; Glasser, et al., 2007). To this end, post-marketing research has become an integral part of the drug's lifecycle (Wise, 2011; Glasser et al., 2007)

\section{Conclusion}

Epidemiologists provide data, methods and strategic direction to optimize product development and commercialization. Key deliverables within the clinical development teams include describing and quantifying disease incidence and prevalence, clinical course, real-world treatment practices, adverse events rates, patient exposure, and the design, analysis and reporting of observational studies. Although an important contribution, data from epidemiological studies should not be viewed in isolation, as evaluation of safety and efficacy includes data from multiple sources including clinical studies, spontaneous adverse event reports and preclinical datasets, and all offer important context.

\section{References}

Bigal, M.E., Serrano, D., Reed, M., \& Lipton, R.B. 2008. Chronic migraine in the population: burden, diagnosis, and satisfaction with treatment. Neurology, Vol. 71, No. 8, pp. 559-566.

Blumenfeld, A., Varon, S., Wilcox, T.K., Buse, D., Kawata, A.K., Manack, A., Goadsby, P.J., \& Lipton, R.B. 2011. Disability, HRQoL and resource use among chronic and episodic migraineurs: Results from the International Burden of Migraine Study (IBMS). Cephalalgia, Vol. 31, No. 3, pp. 301-315.

Briggs, A., Claxton, K., \& Sculpher, M. 2006. Decision Modelling for Health Economic Evaluation (Handbooks in Health Economic Evaluation). Oxford University Press, ISBN 9780198526629, New York, New York, USA.

Buse, D.C., Manack, A., Serrano, D., Turkel, C., \& Lipton, R.B. 2010. Sociodemographic and comorbidity profiles of chronic migraine and episodic migraine sufferers. J Neurol Neurosurg Psychiatry, Vol. 81, No. 4, pp. 428-432.

Buse, D.C., Manack, A.N., Serrano, D., Varon, S.F., Turkel, C.C., \& Lipton, R.B. 2011. Headache impact of chronic and episodic migraine: Predictors of impact from the American Migraine Prevalence and Prevention (AMPP) study. Headache, in press.

Conway, P.H., \& Clancy, C. 2010. Charting a path from comparative effectiveness funding to improved patient-centered health care. JAMA, Vol. 303, No. 10, pp. 985-986.

Doyle, J.J. 2011. The effect of Comparative Effectiveness Research on Drug Development Innovation: A $360^{\circ}$ Value Appraisal, Dove Press, Retrieved from www.dovepress.com/the-effect-of-comparative-effectiveness-research-on-drugdevelopment-i-a6837 
FDA review.org. n.d. The Drug Development and Approval Process. Retrieved from www.fdareview.org/approval_process.shtml

Glasser, S.P., Salas, M., \& Delzell, E. 2007. Importance and challenges of studying marketed drugs: What is a phase IV study? Common clinical research designs, registries, and self-reporting systems. J Clin Pharmacol, Vol. 47, No. 9, pp. 10741086.

Gold, M.R., Siegel, J.E., Russell, L.B., \& Weinstein, M.C. (Eds.) 1996. Cost-Effectiveness in Health and Medicine, Oxford University Press, ISBN 9780195108248, New York, New York, USA.

Hartzema, A.G., Porta, M., \& Tilson, H.H. (Eds.) 1998. Pharmacoepidemiology: An Introduction (3rd edition), Harvey Whitney Books, ISBN 978-0929375182, Cincinnati, $\mathrm{OH}, \mathrm{USA}$.

Katsarava, Z., Manack, A., Yoon, M.-S., Obermann, M., Becker, H., Dommes, P., Turkel, C., Lipton, R.B., \& Diener, H.C. 2011. Chronic migraine: Classification and comparisons. Cephalalgia, Vol. 31, No. 5, pp. 520-529.

Lipton, R.B., Bigal, M.E., Diamond, M., Freitag, F., Reed, M.L., \& Stewart, W.F. 2007. Migraine prevalence, disease burden, and the need for preventive therapy. Neurology, Vol. 68. No. 5, pp. 343-349.

Lipton, R.B. 2009. Tracing transformation: chronic migraine classification, progression, and epidemiology. Neurology, Vol. 72, No. 5 Suppl., pp. S3-S7.

Lipton, R.B., \& Chu, M.K. 2009. Conceptualizing the relationship between chronic migraine and episodic migraine. Expert Rev Neurother, Vol. 9, No. 10, pp. 1451-1454.

Lipton, R.B., Silberstein, S.D., Diener, H.C., Dodick, D.W., Aurora, S.K., Manack, A., DeGryse, R.E., \& Turkel, C.C. 2011. Field testing chronic migraine diagnostic criteria: Assessment of sensitivity and specificity. Abstract and poster presented at the 15th Congress of the International Headache Society, Berlin, Germany, June 2326, 2011.

Manack, A., Turkel, C., \& Silberstein, S. 2009. The evolution of chronic migraine: Classification and nomenclature. Headache, Vol. 49, No. 8, pp. 1206-1213.

Manack, A.N., Buse, D.C., \& Lipton, R.B. 2010. Chronic migraine: Epidemiology and disease burden. Curr Pain Headache Rep, Vol. 15, No. 1, pp. 70-78.

Manack, A., Buse, D.C., Serrano, D., Turkel, C.C., Lipton, R.B. 2011. Rates, predictors, and consequences of remission from chronic migraine to episodic migraine. Neurology, Vol. 76. No. 8, pp. 711-718.

Manack, A.N., Buse, D.C., Serrano, D., Turkel, C., \& Lipton, R.B. 2012. Lost productive time and cost due to headache in chronic migraine and episodic migraine: Results from the American Migraine Prevalence and Prevention (AMPP) study. Abstract submitted to the 54th Annual Scientific Meeting of the America Headache Society, Los Angeles, CA, USA June 21-24, 2012.

Munakata, J., Hazard, E., Serrano, D., Klingman, D., Rupnow, M.F., Tierce, J., Reed, M., \& Lipton, R.B. Economic burden of transformed migraine: Results from the American Migraine Prevalence and Prevention (AMPP) study. Headache 2009, Vol. 49, No. 4, pp. 498-508. 
Murray, R.K, \& McElwee, N.E. 2010. Comparative effectiveness research: critically intertwined with healthcare reform and the future of biomedical innovation. Arch Intern Med, Vol. 170, No. 7, pp. 596-599.

Natoli, J., Manack, A., Dean, B., Butler, Q., Turkel, C., Stovner, L., \& Lipton, R. 2010. Global prevalence of chronic migraine: a systematic review. Cephalalgia, Vol. 30, No. 5, pp. 599-609.

Olesen J. 2006. International Classification of Headache Disorders, Second Edition (ICHD-2): current status and future revisions. Cephalalgia, Vol. 26, No. 12, pp. 1409-1410.

Olesen, J., Bousser, M.G., Diener, H.C., Dodick, D., First, M., Goadsby, P.J., Gobel, H., Lainez, M.J., Lance, J.W., Lipton, R.B., Nappi, G., Sakai, F., Schoenen, J., Silberstein, S.D., \& Steiner, T.J. 2006. New appendix criteria open for a broader concept of chronic migraine. Cephalalgia, Vol. 26, No. 6, pp. 742-746.

Payne, K.A., Varon, S.F., Kawata, A.K., Yeomans, K., Wilcox, T.K,, Manack, A., Buse, D.C., Lipton, R.B., Goadsby, P.J., \& Blumenfeld, A.M. 2011. The International Burden of Migraine Study (IBMS): Study design, methodology and baseline cohort characteristics. Cephalalgia, Vol. 31, No. 10, pp. 1116-1130.

Salas M, Hofman A, Stricker BH. Confounding by indication: an example of variation in the use of epidemiologic terminology. Am J Epidemiol 1999 1;149(11):981983.

Serrano, D., Manack, A.N., Reed, M.L., Buse, D.C., Varon, S., \& Lipton, R.B. 2011. Cost of lost productive time in chronic migraine and episodic migraine: Results from the American Migraine Prevalence and Prevention (AMPP) study. In progress.

Silberstein, S.D., Lipton, R.B., Diener, H.C., Dodick, D.W., Aurora, S.K., Manack, A., DeGryse, R.E., \& Turkel, C.C. 2011. Field testing chronic migraine (CM) diagnostic criteria: Assessments of demographic and headache profiles. Abstract and poster presented at the 15th Congress of the International Headache Society, Berlin, Germany, June 23-26, 2011.

Sox, H.C., \& Greenfield, S. 2009. Comparative effectiveness research: a report from the Institute of Medicine. Ann Intern Med, Vol. 15, No. 3, pp. 203-205.

Stewart, W.F., Wood, G.C., Manack, A., Varon, S.F., Buse, D.C., \& Lipton, R.B. Employment and work impact of chronic migraine and episodic migraine. J Occup Environ Med, Vol. 52, No. 1, pp. 8-14.

Stokes, M., Becker, W.J., Lipton, R.B., Sullivan, S.D., Wilcox, T.K., Wells, L., Manack, A., Proskorovsky, I., Gladstone, J., Buse, D.C., Varon, S.F., Goadsby, P.J., \& Blumenfeld, A.M. 2011. Cost of health care among patients with chronic and episodic migraine in Canada and the USA: Results from the International Burden of Migraine Study (IBMS). Headache, Vol. 51, No. 7, pp. 10581077.

Strom, B.L. (Ed.) 1994. Pharmacoepidemiology (2nd edition), John Wiley \& Sons, ISBN 9780471940586, Chichester, UK.

Tufts 2001 report. Retrieved from www.cptech.org/ip/health/econ/rndcosts.html 
Wise, L. Risks and benefits of (pharmaco)epidemiology. Ther Adv in Drug Saf, Vol. 2, No. 3, pp. 95-102. 


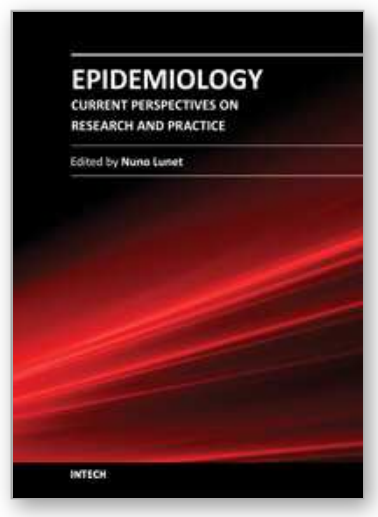

\author{
Epidemiology - Current Perspectives on Research and Practice \\ Edited by Prof. Nuno Lunet
}

ISBN 978-953-51-0382-0

Hard cover, 208 pages

Publisher InTech

Published online 13, March, 2012

Published in print edition March, 2012

This special issue resulted from the invitation made to selected authors to contribute with an overview of a specific subject of their choice, and is based on a collection of papers chosen to exemplify some of the interests, uses and views of the epidemiology across different areas of research and practice. Rather than the comprehensiveness and coherence of a conventional textbook, readers will find a set of independent chapters, each of them of a great interest in their own specialized areas within epidemiology. Taken together, they illustrate the contrast between the attempt to extend the limits of applicability of epidemiological research, and the "regular" scientific activity in this field or an applied epidemiology. Epidemiologists with different levels of expertise and interests will be able to find informative and inspiring readings among the chapters of this book.

\title{
How to reference
}

In order to correctly reference this scholarly work, feel free to copy and paste the following:

Aubrey Manack, Catherine C. Turkel and Haley Kaplowitz (2012). Role of Epidemiological Data Within the Drug Development Lifecycle: A Chronic Migraine Case Study, Epidemiology - Current Perspectives on Research and Practice, Prof. Nuno Lunet (Ed.), ISBN: 978-953-51-0382-0, InTech, Available from: http://www.intechopen.com/books/epidemiology-current-perspectives-on-research-and-practice/role-ofepidemiological-data-within-the-drug-development-lifecycle-a-chronic-migraine-case-study

\section{INTECH}

open science | open minds

\author{
InTech Europe \\ University Campus STeP Ri \\ Slavka Krautzeka 83/A \\ 51000 Rijeka, Croatia \\ Phone: +385 (51) 770447 \\ Fax: +385 (51) 686166 \\ www.intechopen.com
}

\author{
InTech China \\ Unit 405, Office Block, Hotel Equatorial Shanghai \\ No.65, Yan An Road (West), Shanghai, 200040, China \\ 中国上海市延安西路65号上海国际贵都大饭店办公楼 405 单元 \\ Phone: +86-21-62489820 \\ Fax: +86-21-62489821
}


(C) 2012 The Author(s). Licensee IntechOpen. This is an open access article distributed under the terms of the Creative Commons Attribution 3.0 License, which permits unrestricted use, distribution, and reproduction in any medium, provided the original work is properly cited. 